\title{
PRODUKSI DAN PRODUKTIVITAS TUNA OLEH KAPAL TUNA LONGLINE YANG BERBASIS DI PPN PALABUHANRATU
}

\section{PRODUCTIVITY AND PRODUCTION TUNA BY TUNA LONGLINE BASED ON PPN PALABUHANRATU}

\author{
Mohammad Imron ${ }^{1}$, Roza Yusfiandayani ${ }^{1}$, Mulyono S. Baskoro ${ }^{1}$ \\ ${ }^{1}$ Departemen Pemanfaatan Sumberdaya Perikanan, \\ Fakultas Perikanan dan Ilmu Kelautan, Institut Pertanian Bogor \\ Korespondensi: mohammadim@apps.ipb.ac.id,ocha_roza@apps.ipb.ac.id, baskoro.mul@gmail.com
}

\begin{abstract}
Tuna fishing productivity can be seen from the production of landed production per attempt. The archipelago fishing port Palabuhanratu has become one of the active fishing ports in the southern coastal region in Java Island and it's one of the centers of capture fisheries in the area of West Java Province. Tuna longline is an industrial-scale fishing unit to catch tuna as an export commodity. Tuna production in PPN Palabuhanratu experienced had a significant increase from 2010 to 2014. In 2014-2018 tuna production in PPN Palabuhanratu experienced had a quite drastic decline. In 2019, production will increase to 1,091,612 tons. Landing Per Unit Effort (LPUE) is used in fisheries research to indicate the abundance of resources used to conduct stock assessments when estimating the relative abundance of an exploited species. The composition of tuna catches by longline tuna vessels consists of yellowfin tuna (Thunnus albacores), big eye tuna (Thunnus obesus), and albakor tuna (Thunnus alalunga). Tuna production which was landed at PPN Palabuhanratu from 2010-2019 experienced is fluctuative. In 2010 the production of yellowfin tuna was 444,952 tons, big eye tuna was 979,189 tons, albakor tuna was 122,671 tons. In 2019 the production of yellowfin tuna was 617,992 tons, big eye tuna was 240,487 tons, albakor tuna was 233,133 tons. The highest productivity occurred in yellowfin tuna in 2014 with a LPUE value of 6,09 with a production of 2,448,171 tons with a total effort of 402. Productivity has fluctuated every year.
\end{abstract}

Keywords: LPUE, Palabuhanratu, productivity, tuna longline

\begin{abstract}
ABSTRAK
Produktivitas penangkapan tuna dapat dilihat dari produksi penangkapan yang didaratkan di pelabuhan (landing) per upaya penangkapan (effort). Pelabuhan Perikanan Nusantara (PPN) Palabuhanratu menjadi salah satu pelabuhan perikanan yang aktivitas perikanannya tergolong aktif di wilayah pesisir selatan Pulau Jawa dan menjadi salah satu pusat kegiatan perikanan tangkap di wilayah Propinsi Jawa Barat. Produksi ikan tuna di PPN Palabuhanratu mengalami peningkatan yang cukup signifikan dari tahun 2010 sampai tahun 2019. Pada tahun 2014-2018 produksi ikan tuna di PPN Palabuhanratu mengalami penurunan yang cukup drastis. Pada tahun 2019, produksi kembali meningkat menjadi 1,091,612 ton. Landing Per Unit Effort (LPUE) digunakan dalam penelitian perikanan untuk mengindikasikan kelimpahan sumberdaya yang digunakan untuk melakukan stock assessment ketika mengestimasi kelimpahan relatif dari suatu spesies yang dieksploitasi. Komposisi hasil tangkapan tuna oleh kapal tuna longline terdiri atas ikan tuna sirip kuning (Thunnus albacores), tuna mata besar (Thunnus obesus), ikan tuna albakor (Thunnus alalunga). Produksi tuna yang didaratkan di PPN Palabuhanratu dari tahun 2010-2019 mengalami fluktuasi. Pada tahun 2010 produksi ikan tuna sirip kuning sebesar 444,952 ton, ikan tuna mata besar sebesar 979,189 ton, ikan tuna albakor sebesar 122,671 ton. Pada tahun 2019 produksi ikan tuna sirip kuning sebesar 617,992 ton, ikan tuna mata besar sebesar 240,487 ton, ikan tuna albakor sebesar 233,133 ton. Produktivitas tertinggi terjadi pada ikan tuna sirip kuning tahun 2014 dengan nilai LPUE sebesar 6,09 dengan produksi sebesar 2,448,171 ton dengan jumlah effort 402. Produktivitas mengalami fluktuasi setiap tahunnya.
\end{abstract}

Kata kunci: LPUE, Palabuhanratu, produktivitas, tuna longline 


\section{PENDAHULUAN}

Sektor perikanan memiliki kontribusi yang besar terhadap pertumbuhan ekonomi di beberapa negara maju seperti Amerika Serikat, Jepang, China dan negara-negara Eropa. Hal ini dipertegas oleh pernyataan Fauzi (2010) bahwa sektor perikanan di beberapa negara di dunia telah menjadi sumber "energi" pertumbuhan ekonomi dan juga menjadi "mesin pertumbuhan" ekonomi regional. Hal ini pun terjadi di Indonesia, dimana sektor perikanan terus memberikan peningkatan kontribusi terhadap pertumbuhan ekonomi sehingga pemerintah memberikan perhatian lebih. Perhatian tersebut diimplementasikan melalui dukungan kebijakan fiskal dan non fiskal yang bertujuan untuk meningkatkan kesejahteraan rakyat, terutama nelayan (Samosir 2014). Hal tersebut menegaskan bahwa sumber daya perikanan adalah aset penting negara yang jika dikelola dengan baik akan memberlkan manfaat yang maksimum bagi masyarakat (Fauzi dan Anna 2002).

Lokasi PPN Palabuhanratu berhadapan langsung dengan Samudera Hindia, dimana daerah penangkapannya dalam pengoperasian rawai tuna relatif cukup jauh dan di luar teluk atau sudah di wilayah perairan Samudera Hindia. Penangkapan ikan di Palabuhanratu, Jawa Barat umumnya dilakukan sepanjang tahun dan dikenal dengan tiga musim penangkapan yaitu musim banyak ikan, musim sedang ikan, dan musim kurang ikan. Musim banyak ikan dimana ikan sangat melimpah yang terjadi pada bulan Juni-September, musim sedang ikan pada bulan Maret-Mei dan Oktober-November sedangkan musim kurang ikan ditandai dengan sedikitnya hasil tangkapan yang terjadi pada bulan Desember-Februari (Handriana 2007).

Perikanan tuna di Indonesia merupakan salah satu industri perikanan yang semakin berkembang. Indonesia memilikikeunggulan geografis yaitu beradadi antara dua Samudera Hindia dan Samudera Pasifik. Hal tersebut membuat Indonesia menjadi negara penting bagi perikanan tuna global. Selain itu, Indonesia telah menjadi anggota Organisasi Pengelolaan Perikanan Regional atau RegionalFisheries Management Organisations (RFMOs), sehingga perikanan tuna di Indonesia semakin diperhatikan. Salah satu unit penangkapan yang ada di PPN Palabuhanratu adalah rawai tuna (tuna longline). Rawai tuna termasuk unit penangkapan skala industri untuk menangkap ikan tuna sebagai komoditi ekspor. Alat tangkap rawai tuna merupakan alat tangkap yang pasif dan selektif terhadap jenis ikan yang ditangkap, sehingga rawai tuna termasuk alat tangkap yang ramah lingkungan.

Produksi ikan tuna di PPN Palabuhanratu mengalami peningkatan yang cukup signifikan dari tahun 2010 sampai tahun 2014. Pada tahun 2014-2018 produksi ikan tuna di PPN Palabuhanratu mengalami penurunan yang cukup drastis. Pada tahun 2019, produksi kembali meningkat menjadi 1,091,612 ton (Data Statistik Perikanan PPN Pelabuhan Ratu 2010-2019).

Penangkapan ikan tuna di Palabuhanratu Jawa Barat dilakukan dengan menggunakan alat tangkap tuna longline dan pancing tonda. Hasil wawancara dengan nelayan dan petugas di PPN Pelabuhan Ratu, diinformasikan bahwa kapal-kapal tuna longline masuk ke Palabuhanratu mulai tahun 2001 dari Cilacap untuk melakukan bongkar muat, kemudian pada tahun 2004 mulai dipindahkan ke Palabuhanratu. Tuna longline merupakan alat tangkap yang efektif menangkap ikan tuna. Alat ini juga selektif terhadap hasil tangkapannya.

Pemanfaatan perikanan tuna yang berkelanjutan hanya bisa dilaksanakan apabila berorientasi pada kepentingan dan mendapat dukungan dari masyarakat. Partisipasi masyarakat dalam pemanfaatan perikanan tuna yang berkelanjutan sangat diperlukan agar dapat berjalan dengan baik. Bentuk dari dukungan masyarakat dapat dilihat dengan menentukan nilai ekonomi atau valuasi perikanan tuna di Palabuhanratu, Jawa Barat. Keberlanjutan usaha dan sumberdaya perikanan tuna perlu dilakukan guna membantu pemerintah dalam mengelola perikanan tuna dengan sebaik mungkin, hingga tidak hanya untuk dieksploitasi secara terus menerus tetapi akan tetap terus terjaga kelestariannya dengan pengelolaan yang optimal. Salah satu unit penangkapan ikan tuna yang ada di perairan di PPN Palabuhanratu adalah rawai tuna (tuna longline). Rawai tuna termasuk unit penangkapan yang pasif dan selektif terhadap jenis ikan yang ditangkap sehingga rawai tuna termasuk alat tangkap yang ramah lingkungan. Perikanan tuna tergolong pada perikanan skala industri 
karena ukuran kapal nya yang relatif besar dan komoditi hasil tangkapannya juga sebagai komoditi ekspor.

Terjadinya fluktuasi produktivitas tuna di PPN Palabuhanratu diperkirakan disebabkan oleh kegiatan IUU Fishing salah satunya adalah kegiatan transhipment. Kegiatan alih muat merupakan kegiatan yang cukup strategis dalam pelaksanaan usaha perikanan pada kapal tuna longline namun dengan dikeluarkannya Peraturan Menteri Kelautan dan Perikanan Republik Indonesia nomor 57/permen-kp/2014 tentang Perubahan Kedua atas Peraturan Menteri Kelautan dan Perikanan Nomor PER.30/MEN/2012 tentang Usaha Perikanan Tangkap di Wilayah Pengelolaan Perikanan Negara Republik Indonesia sebagai dasar pelarangan pindah muatan di laut (transhipment) (KKP 2014).

Menurut Keputusan Menteri Kelautan dan Perikanan Republik Indonesia Nomor 61/KEPMEN-KP/2014, produktivitas kapal penangkap ikan merupakan tingkat kemampuan memperoleh hasil tangkapan ikan yang ditetapkan dengan mempertimbangkan ukuran tonnage kapal; bahan kapal yang digunakan, kayu, besi, atau fiber; kekuatan mesin kapal; jenis alat penangkapan ikan yang digunakan; jumlah trip operasi penangkapan per tahun; kemampuan tangkap rata-rata per trip dan wilayah penangkapan ikan. Produktivitas kapal penangkap ikan per Gross Tonnage (GT) per tahun ditetapkan berdasarkan perhitungan jumlah hasil tangkapan ikan per kapal dalam 1 (satu) tahun dibagi besarnya
GT kapal yang bersangkutan. Produktivitas kapal penangkap ikan sebagaimana dimaksud tersebut ditetapkan per Gross Tonnage (GT) per tahun berdasarkan perhitungan jumlah hasil tangkapan ikan per kapal dalam 1 (satu) tahun dibagi besarnya GT kapal yang bersangkutan.

Tujuan dari penelitian ini adalah menghitung produktivitas penangkapan (LPUE) 3 jenis tuna yakni ikan tuna sirip kuning (Thunnus albacores), tuna mata besar (Thunnus obesus), dan ikan tuna albakor (Thunnus alalunga) yang mendaratkan hasil tangkapan di PPN Palabuhanratu dari tahun 2010-2019.

\section{METODE PENELITIAN}

\section{Waktu dan tempat penelitian}

Penelitian ini dilakukan di Pelabuhan Perikanan Nusantara Palabuhanratu pada tahun 2010-2019. Peta lokasi penelitian dapat dilihat pada Gambar 1.

\section{Jenis dan sumber data}

Jenis data yang dikumpulkan pada penelitian adalah data sekunder. Data sekunder yang dibutuhkan data produksi hasil tangkapan ikan tuna yang didaratkan di Pelabuhan Perikanan Nusantara Palabuhanratu dan data logbook kapal tuna longline yang berbasis di Palabuhanratu dari tahun 2010-2019 (PPN Palabuhanratu 2010 - 2019).

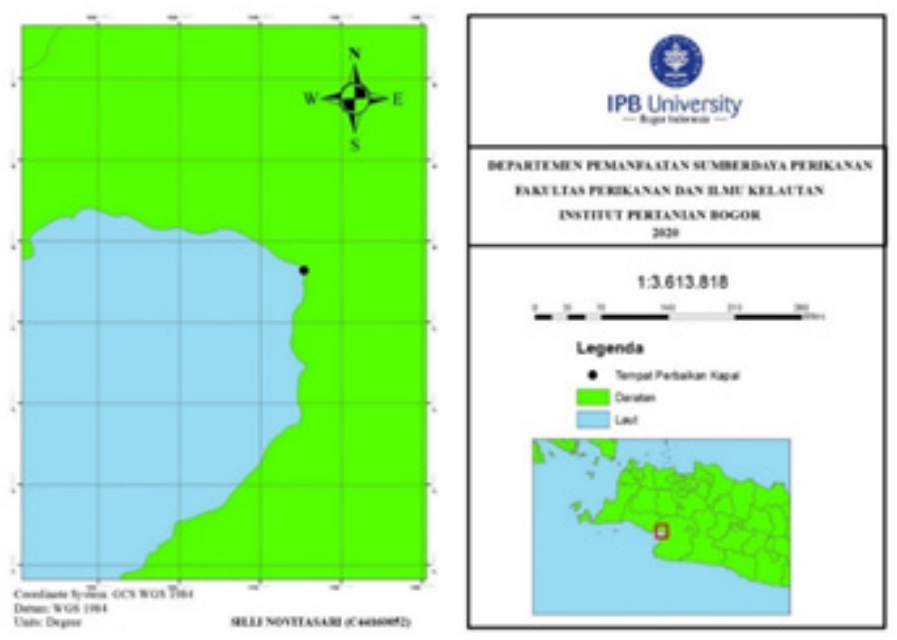

Gambar 1. Peta lokasi penelitian 


\section{Analisis data}

Landing Per Unit Effort (LPUE) digunakan dalam penelitian perikanan untuk mengindikasikan kelimpahan sumberdaya yang digunakan untuk melakukan stock assessment ketika mengestimasi kelimpahan relatif dari suatu spesies yang dieksploitasi. LPUE menghitung hasil tangkapan yang benarbenar ditangkap dan dijual di pelabuhan dengan melakukan pelaporan. Menurut Metri dan Perez (2014) disebutkan bahwa hasil tangkapan sampingan biasanya dibuang di atas kapal sehingga perhitungan hasil tangkapan utama lebih efektif, jika hasil tangkapan sampingan relatif stabil maka LPUE dapat memberikan perikiraan CPUE yang lebih baik. Hasil tangkapan landing biasanya dapat menggambarkan jumlah spesimen atau berat hasil tangkapan, dan "unit effort" diwakili oleh nilai lamanya suatu unit penangkapan ikan menggunakan alat tangkapanya (contoh: jumlah kapal ketika soaking time per satuan waktu). LPUE dapat digunakan dalam berbagai cara, tergantung dari data yang tersedia dan digunakan bedasarkan asumsi yang berbeda. Model Regresi merupakan salah satu model yang umum digunakan yang bertujuan untuk melakukan standardisasi indeks dan menghilangkan bias. Secara umum perhitungan nilai LPUE dapat dirumuskan sebagai:

$$
L P U E=\text { Landing } / \text { Trips }
$$

Keterangan:

LPUE : Landing Per Unit Effort

Landing : Total tangkapan yang didaratkan di pelabuhan oleh setiap kapal per tahun

Trips : Jumlah trip kapal per tahun

Menurut Setyorini et al. (2009), produktivitas alat tangkap dihitung dengan persamaan sebagai berikut:

Produktivitas rata - rata $=\frac{\sum \text { Produksi }}{\sum \text { Upaya penangkapan }}$

Untuk menganalisis produktivitas rawai tuna longline di PPN Palabuhanratu, diolah dari data hasil tangkapan tuna longline yang berukuran 20-30 GT yang mendaratkan ikannya di PPN Palabuhanratu dari tahun 2010 sampai tahun 2019.

\section{HASIL DAN PEMBAHASAN}

\section{Karakteristik Palabuhanratu di Kabupaten Sukabumi}

Secara geografis, Kabupaten Sukabumi terletak pada posisi $06^{\circ} 57^{\prime}-07^{\circ} 25^{\prime}$ LS dan $106^{\circ} 49^{\prime}-107^{\circ} 00^{\prime}$ BT, sedangkan Palabuhanratu berada pada $06^{\circ} 57^{\prime}-07^{\circ} 07^{\prime}$ LS dan $106^{\circ} 22^{\prime}-106^{\circ} 33^{\prime}$ BT (Pariwono et al. 1998). Topografi wilayah pesisir pantai di Kabupaten Sukabumi adalah bertekstur kasar, sebagian besar wilayahnya merupakan dataran bergelombang dan terdiri atas daerah perbukitan, daerah aliran sungai serta pantai. Wilayah pesisir pantai dan teluk yang ada di Kabupaten Sukabumi berhubungan langsung dengan Samudra Hindia.

Teluk Palabuhanratu merupakan teluk terbesar yang pernah ada di sepanjang pantai selatan Pulau Jawa. Panjang garis pantai lebih kurang $115 \mathrm{~km}$ dimulai dari Desa Cibareno yang berada diperbatasan antara Kabupaten Sukabumi dengan Provinsi Banten sampai dengan Tegalbuleud berbatasan dengan Kabupaten Cianjur. Ditinjau dari topografi dasar laut, perairan hingga kedalaman 200 m di teluk tersebut dapat dijumpai hingga jarak sekitar 300 $\mathrm{m}$ dari garis pantai. Setelah itu dasar laut menurun dengan tajam mencapai kedalaman lebih dari $600 \mathrm{~m}$ di bagian tengah teluk (Pariwono et al. 1998).

\section{Kapal tuna longline}

Perikanan rawai tuna (longline) mulai beroperasi di PPN Palabuhanratu pada tahun 2003. Perkembangan jumlah unit kapal rawai tuna cenderung bertambah pada setiap tahunnya. Spesifikasi kapal pancing rawai tuna yang diikuti pengoperasiannya adalah kapal yang terbuat dari bahan kayu dan fiberglass. Ukuran kapal rawai tuna longline yang mendominasi di Palabuhanratu, Jawa Barat yaitu ukuran 20-30 GT. Umumnya panjang kapal sekitar 16-20 meter. Mesin penggerak menggunakan mesin dalam (inboard engine). Ukuran mesin kapal yaitu antara 255 PK dan bahan bakar menggunakan solar. Kapal motor yang sebagian besar berbahan dasar kayu, adapun beberapa kapal berbahan dasar fiber. Kapal ukuran 20-30 GT ratarata memiliki 7 buah palka dengan sistem pendingin frezeer air. Pada Gambar 2 dan 
3 disajikan gambar kapal tuna longline yang bersandar di PPN Palabuhanratu dan ilustrasi alat tangkap tuna longline.

\section{Produksi tuna longline}

Komposisi hasil tangkapan tuna oleh kapal tuna longline terdiri atas ikan tuna sirip kuning (Thunnus albacores), tuna mata besar (Thunnus obesus), dan ikan tuna albakor (Thunnus alalunga). Produksi tuna yang didaratkan di PPN Palabuhanratu dari tahun 2010-2019 mengalami fluktuasi (Gambar 4) (Data PPN Palabuhanratu tahun 2010-2019). Pada tahun 2010 produksi ikan tuna sirip kuning sebesar 444,952 ton, ikan tuna mata besar sebesar 979,189 ton, ikan tuna albakor sebesar 122,671 ton. Pada tahun 2011 produksi ikan tuna sirip kuning sebesar 867,241 ton, ikan tuna mata besar sebesar $1,626,447$ ton, ikan tuna albakor sebesar 235,524 ton. Pada tahun 2012 produksi ikan tuna sirip kuning sebesar $1,051,808$ ton, ikan tuna mata besar sebesar $1,879,960$ ton, ikan tuna albakor sebesar 394,964 ton. Pada tahun 2013 produksi ikan tuna sirip kuning sebesar 1,612,687 ton, ikan tuna mata besar sebesar 1,958,432 ton, ikan tuna albakor sebesar 547,087 ton. Pada tahun 2014 produksi ikan tuna sirip kuning sebesar 2,448,171 ton, ikan tuna mata besar sebesar 2,049,505 ton, ikan tuna albakor sebesar $1,189,582$ ton. Pada tahun 2015 produksi ikan tuna sirip kuning sebesar 422,880 ton, ikan tuna mata besar sebesar 427,450 ton, ikan tuna albakor sebesar 442,562 ton. Pada tahun 2016 produksi ikan tuna sirip kuning sebesar 180,955 ton, ikan tuna mata besar sebesar 182,121 ton, ikan tuna albakor sebesar
176,022 ton. Pada tahun 2017 produksi ikan tuna sirip kuning sebesar 73,764 ton, ikan tuna mata besar sebesar 69,488 ton, ikan tuna albakor sebesar 105,505 ton. Pada tahun 2018 produksi ikan tuna sirip kuning sebesar 26,769 ton, ikan tuna mata besar sebesar 25,882 ton, ikan tuna albakor sebesar 25,923 ton. Pada tahun 2019 produksi ikan tuna sirip kuning sebesar 617,992 ton, ikan tuna mata besar sebesar 240,487 ton, ikan tuna albakor sebesar 233,133 ton. Grafik produksi tuna yang didaratkan di PPN Palabuhanratu tahun 2010-2019 disajikan pada Gambar 4, sedangkan pada Gambar 5 disajikan jumlah kapal yang tercatat mendaratkan hasil tangkapannya di PPN Palabuhanratu.

Pada tahun 2010 jumlah trip kapal longline sebanyak 1,077 trip. Pada tahun 2011 jumlah trip kapal longline sebanyak 398 trip. Pada tahun 2012 jumlah trip kapal longline sebanyak 455 trip. Pada tahun 2013 jumlah trip kapal longline sebanyak 384 trip. Pada tahun 2014 jumlah trip kapal longline sebanyak 402 trip. Pada tahun 2015 jumlah trip kapal longline menurun ke angka 267 trip. Pada tahun 2016 jumlah trip kapal longline sebanyak 149 trip. Pada tahun 2017 jumlah trip kapal longline sebanyak 114 trip. Pada tahun 2018 jumlah trip kapal longline hanya mencapai angka 113 trip. Pada tahun 2019 jumlah trip kapal longline mulai meningkat menjadi 132 trip. Jumlah trip kapal longline tercatat sebanyak 3,491 trip dengan rata-rata per tahun sebanyak 349 trip. Jumlah trip tertinggi yaitu pada tahun 2010 sebanyak 1,077 trip, dan terendah pada tahun 2018 sebanyak 113 trip.

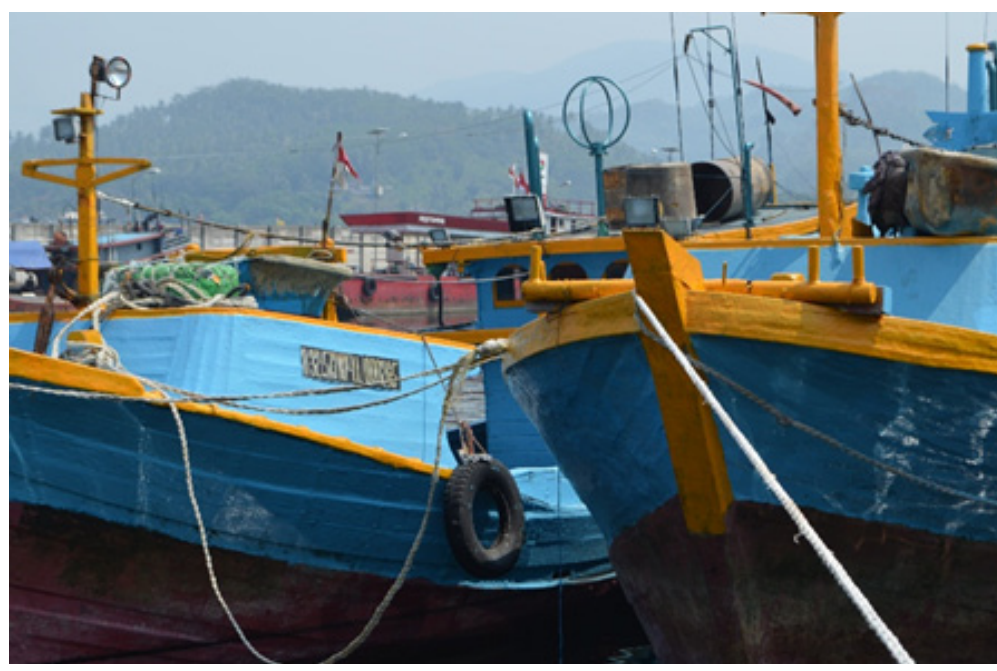

Gambar 2. Kapal tuna longline di PPN Palabuhanratu 


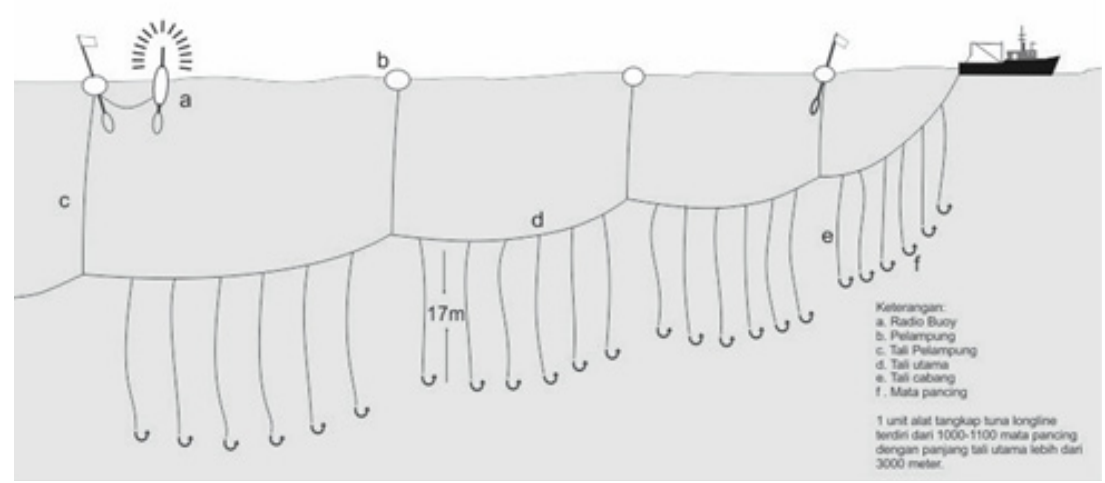

Gambar 3. Alat tangkap tuna longline

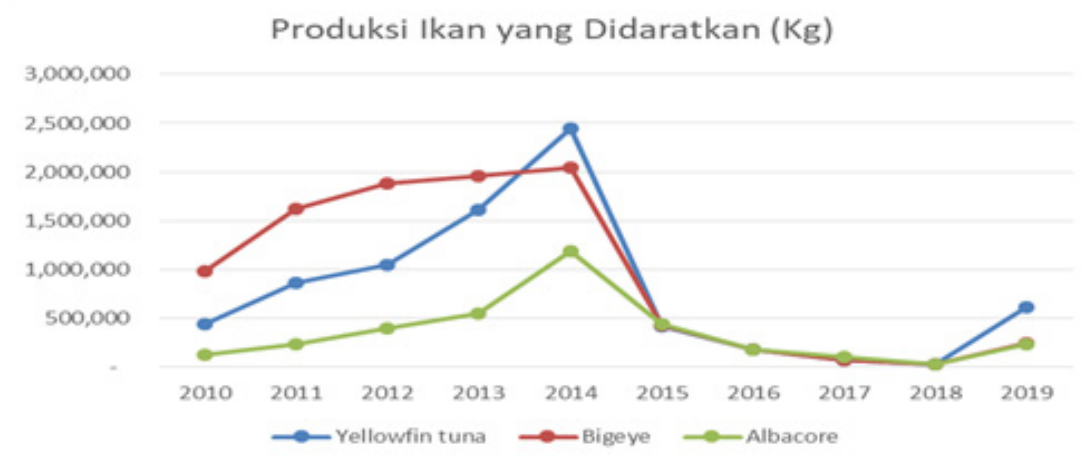

Gambar 4. Grafik produksi ikan tuna yang didaratkan (kg)

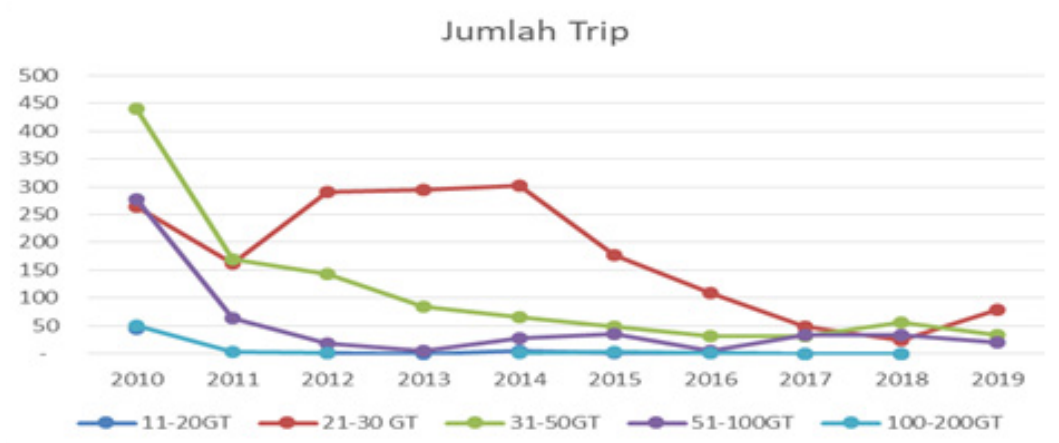

Gambar 5. Grafik jumlah trip kapal

\section{Produktivitas}

Secara umum yang banyak didapat dalam buku-buku teks, produktivitas mengandung arti sebagai perbandingan antara hasil yang dicapai (output) dengan keseluruhan sumberdaya yang digunakan (input). Dengan kata lain bahwa produktivitas memiliki dua dimensi, pertama: suatu efektivitas yang mengarah kepada pencapaian untuk kerja yang maksimal, yaitu pencapaian target yang berkaitan dengan kualitas, kuantitas, dan waktu, kedua yaitu efisiensi yang berkaitan dengan upaya membandingkan masukan dengan realisasi penggunaannya atau bagaimana pekerjaan tersebut dilaksanakan.

Menurut Mangkuprawira (2007), produktivitas perikanan tangkap adalah rasio output dan input suatu proses produksi dalam periode tertentu. Input terdiri dari manajemen, tenaga kerja, biaya produksi, dan peralatan serta waktu. Output meliputi produksi, produk penjualan, pendapatan, pangsa pasar, dan kerusakan produk.

Menurut Sinungan (2008), secara umum produktivitas diartikan sebagai hubungan antara hasil nyata maupun fisik (barang atau jasa) dengan masuknya yang sebenarnya. Misalnya "produktivitas 
adalah ukuran efisiensi produktif". Suatu perbandingan antara hasil keluaran dan masuk atau "output: input". Masukan sering dibatasi dengan masukan tenaga kerja, sedangkan keluaran diukur dalam kesatuan fisik bentuk dan nilai.

$$
\text { Menurut Mulyadi (2000), }
$$

produktivitas didefinisikan sebagai hasil yang didapat dari setiap proses produksi dengan menggunakan satu atau lebih faktor produksi. Produktivitas biasanya dihitung sebagai indek, rasio output (keluaran), disbanding input (masukan). Produktivitas dapat dinyatakan dalam ukuran fisik (physical productivity) dan ukuran finansial (financial productivity), sedangkan efisiensi dalam pengertian ekonomi antara lain:

a. Cost Efficiency: kemampuan untuk memproduksi pada tingkat tertentu dengan biaya yang lebih murah dibandingkan dengan para produsen lain atau dengan biaya yang sama memproduksi pada tingkat yang lebih tinggi; dan

b. Technical Efficiency: kemampuan untuk mengahasilkan luaran sebesar mungkin dari jumlah masukan tertentu atau menghasilkan jumlah luaran yang sama dengan masukan sekecil mungkin.

Menurut Keputusan Menteri Kelautan dan Perikanan Republik Indonesia Nomor 61/KEPMEN-KP/2014, produktivitas kapal penangkap ikan merupakan tingkat kemampuan memperoleh hasil tangkapan ikan yang ditetapkan dengan mempertimbangkan ukuran tonnage kapal; bahan kapal yang digunakan, kayu, besi atau fiber; kekuatan mesin kapal; jenis alat penangkapan ikan yang digunakan; jumlah trip operasi penangkapan per tahun; kemampuan tangkap ratarata per trip dan wilayah penangkapan ikan. Produktivitas kapal penangkap ikan per gross tonnage (GT) per tahun ditetapkan berdasarkan perhitungan jumlah hasil tangkapan ikan per kapal dalam 1 (satu) tahun dibagi besarnya GT kapal yang bersangkutan.

Produktivitas sebagai pembanding antara keluaran dan masukan, misalnya indikasi terjadinya kenaikan produktivitas adalah:

1. Apabila keluaran meningkat, masukan berkurang;

2. Apabila keluaran tetap, masukan tetap;

3. Apabila keluaran meningkat, masukan meningkat, tetapi peningkatan masukan lebih kecil dibandingkan dengan peningkatan keluaran; dan

4. Apabila keluaran menurun, masukan menurun, tetapi penurunan masukan lebih besar dibandingkan penurunan keluaran.

Jadi definisi produktivitas bukanlah hanya satu masalah teknis maupun manajerial tetapi merupakan satu masalah yang kompleks, merupakan masalah yang berkenan dengan badan-badan pemerintahan, serikat buruh, dan lembagalembaga sosial lainya, yang semakin berbeda tujuannya akan semakin berbeda pula definisi produktivitasnya. Namun jika semua pihak setuju terhadap tujuan umumnya tersebut dengan segala kekurangan dan kelebihannya, maka definisi produktivitas itu diharapkan dapat memberikan gambaran yang lebih umum bagi Negara maupun bagi bagian ekonomi yang berbeda-beda. Dan dari pendapat ini maka indikator pokok peningkatan produktivitas itu menurunkan tingkatan unit terpadu dengan unit output (Sinungan 2008).

Produktivitas tertinggi tercatat pada tahun 2014 sebanyak 14,15 ton/trip sedangkan produktivitas terendah tercatat pada tahun 2018 sebanyak 0,7 ton/trip. Grafik dapat dilihat pada Gambar 6.

Produksi tuna yang didaratakan di PPN Palabuhanratu dari tahun 2010-2019 didominasi oleh ikan sirip kuning diikuti oleh ikan tuna albakor, ikan tuna mata besar, dan ikan tuna sirip kuning, namun terlihat pada Gambar 6 produksi keempat jenis tuna mengalami penurunan dari tahun 2015 sampai dengan 2018. Salah satu penyebabnya dikarenakan adanya kegiatan transshipment, walaupun aturan ini sudah diberlakukan sejak tahun 2014 namun aturan ini terus diperketat dalam pelaksanaanya sehingga berdampak pada penurunan produksi ikan yang tercatat di pelabuhan. Namun pada tahun 2019 produksi sedikit mengalami peningkatan hasil produksi. Produktivitas tuna didapatkan dari data hasil produksi dan jumlah effort yang dilakukan sehingga dapat mengetahui trend dari pengakapan ikan.

Berikut disajikan pada Gambar 7 mengenai produktivitas dari ketiga jenis ikan tuna yang didaratkan di PPN Palabuhanratu dari tahun 2010-2019. Produktivitas ikan tuna sirip kuning tertinggi terjadi pada tahun 2014 dengan nilai LPUE sebesar 6,09 dengan produksi sebesar 2,448,171 ton dengan jumlah effort 402. Produktivitas terendah terjadi pada tahun 2018 dengan nilai LPUE produksi sebesar 0,24 dengan produksi sebesar 26,769 ton dengan jumlah effort 113. 


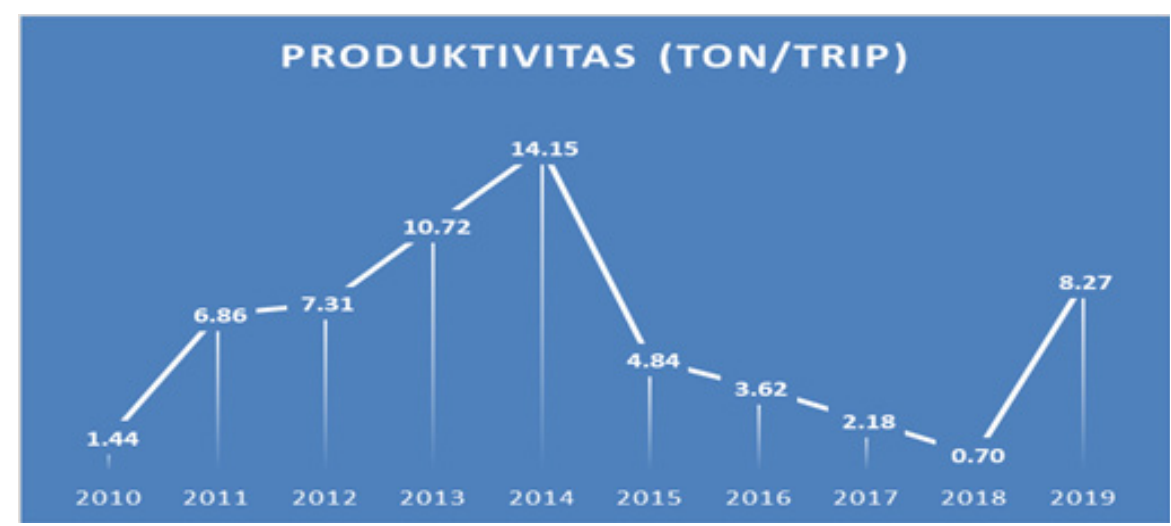

Gambar 6. LPUE ikan tuna dari tahun 2010-2019

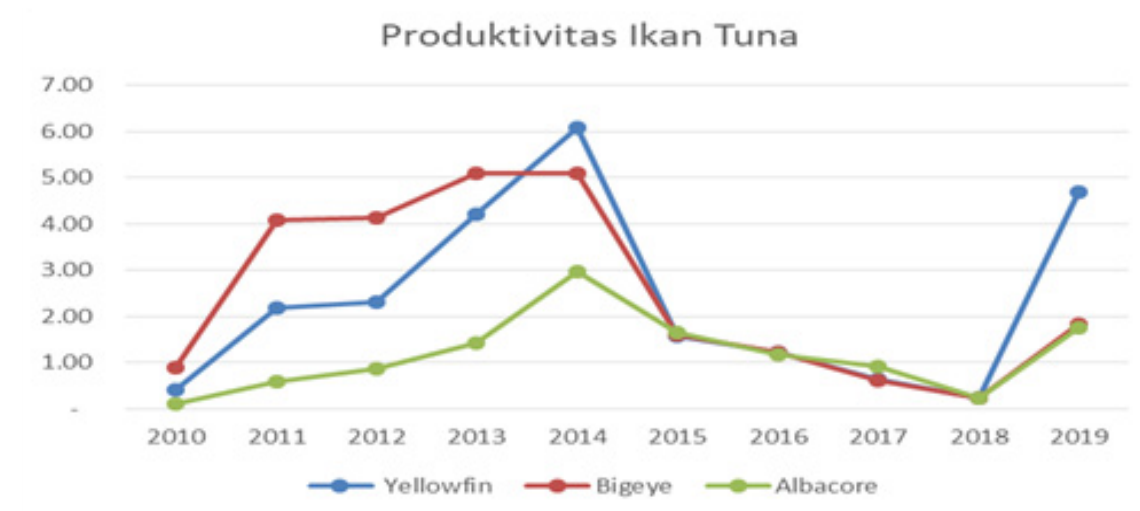

Gambar 7. Produktivitas ikan tuna yellow fin, big eye, dan albacore

\section{Analisis produktivitas tuna longline}

Halimah (2017) dalam penelitiannya disebutkan bahwa implikasi dari pemberlakuan kebijakan pelarangan transhipment tersebut juga cukup berdampak terhadap kegiatan operasional kapal di PPS Nizam Zachman Jakarta. Volume tangkapan ikan yang didaratkan di PPS Nizam Zachman Jakarta berdasarkan jenis kapal tahun 2012-2015 cenderung menurun. Demikian halnya dengan kondisi di PPN Palabuhanratu.

Produktivitas ikan tuna mata besar tertinggi terjadi pada tahun 2013 dan 2014 dengan nilai LPUE sebesar 5,10 dengan produksi sebesar $1,958,432$ ton pada tahun 2013 dan 2,049,505 pada tahun 2014 dengan jumlah effort 384 pada tahun 2013 dan 402 pada tahun 2014. Produktivitas terendah terjadi pada tahun 2018 dengan nilai LPUE produksi sebesar 0,23 dengan produksi sebesar 25,882 ton dengan jumlah effort 113.

Produktivitas ikan tuna albakor mengalami fluktuasi setiap tahunnya. Produktivitas tertinggi terjadi pada tahun 2018 dengan nilai LPUE 2,96 dengan produksi sebesar 1,189,582 ton dengan jumlah effort 402. Produktivitas terendah terjadi pada tahun 2010 dengan nilai LPUE produksi sebesar 0,11 dengan produksi sebesar 122,671 ton dengan jumlah effort 1,077 .

\section{KESIMPULAN DAN SARAN}

\section{Kesimpulan}

Komposisi hasil tangkapan tuna oleh kapal tuna longline terdiri atas ikan tuna sirip kuning (Thunnus albacores), tuna mata besar (Thunnus obesus), dan ikan tuna albakor (Thunnus alalunga). Produktivitas tertinggi terjadi pada ikan tuna sirip kuning tahun 2014 dengan nilai LPUE sebesar 6,09 dengan produksi sebesar 2,448,171 ton dengan jumlah effort 402. Produktivitas mengalami fluktuasi setiap tahunnya. Produktivitas terendah terjadi pada ikan tuna albakor tahun 2010 dengan nilai LPUE produksi sebesar 0,11 dengan produksi sebesar 122,671 ton dengan jumlah effort 1,077 . 


\section{Saran}

Diperlukan penelitian lainnya mengenai ukuran ikan hasil tangkapan di PPN Palabuhanratu yang ditangkap dengan alat tangkap tuna longline dan juga penelitian tentang alat tangkap lainnya yang menangkap ikan tuna.

\section{DAFTAR PUSTAKA}

Fauzi A, Anna Z. 2002. Penilaian Depresiasi Sumberdaya Perikanan sebagai Bahan Pertimbangan Penentuan Kebijakan Pembangunan Perikanan. Jurnal Pesisir dan Lautan. 4(2): 3649.

Fauzi A. 2010. Ekonomi Perikanan "Teori, Kebijakan dan Pengelolaan". PT Gramedia Pustaka Utama. Jakarta.

Halimah I. 2017. Pengaruh Kebijakan Pelarangan Transhipment Terhadap Perusahaan Pengekspor Ikan Studi Kasus Industri Perikanan PPS Nizam Zachman Jakarta. [Skripsi]. Bogor: Institut Pertanian Bogor.

Handriana J. 2007. Pengoperasian Pancing Tonda di Perairan Selatan Teluk Palabuhanratu, Sukabumi Jawa Barat [Skripsi]. Bogor: Institut Pertanian Bogor.

[KKP] Kementrian Kelautan dan Perikanan. 2014. Siaran Pers: Potensi Tuna Indonesia Tertinggi di Dunia. http://kkp.go.id/index. php/arsip/c/10421/PotensiTuna-Indonesia-Tertinggi-DiDunia/?category_id. [15 September 2015].

Mangkuprawira S. 2007. Manajemen Mutu Sumberdaya Manusia. PT Gahlia Indonesia. $36 \mathrm{hlm}$.

Metri CB, Perez JAA. 2014. A LPUE (Landing per Unit Effort) Analysis of the Trawl Fishery for the Coastal Shrimps Artemesia longinaris and Pleoticus muelleri off Southern Brazil. Brazilian J. Oceanogr. 62(4): 235-245. DOI: 10.1590/S167987592014061306204.

Mulyadi. 2000. Total Quality Manajemen. PT. Aditya Media Pustaka bekerjasama dengan UGM Press, Yogyakarta.

Pariwono JI, Eidman M, Santoso R, Purba M, Prartono T, Widodo, Djuariah U, Hutapea JH. 1988. Studi Upwelling di Perairan Selatan Pulau Jawa. Fakultas Perikanan Institut Pertanian Bogor. Bogor. 75 hlm.
PPN Palabuhanratu Kementrian Kelautan dan Perikanan. 2011. Buku Laporan Tahunan Statistik Perikanan Tangkap Tahun 2010. PPN Palabuhanratu. Sukabumi.

PPN Palabuhanratu Kementrian Kelautan dan Perikanan. 2012. Buku Laporan Tahunan Statistik Perikanan Tangkap Tahun 2011. PPN Palabuhanratu. Sukabumi.

PPN Palabuhanratu Kementrian Kelautan dan Perikanan. 2013. Buku Laporan Tahunan Statistik Perikanan Tangkap Tahun 2012. PPN Palabuhanratu. Sukabumi.

PPN Palabuhanratu Kementrian Kelautan dan Perikanan. 2014. Buku Laporan Tahunan Statistik Perikanan Tangkap Tahun 2013. PPN Palabuhanratu. Sukabumi.

PPN Palabuhanratu Kementrian Kelautan dan Perikanan. 2015. Buku Laporan Tahunan Statistik Perikanan Tangkap Tahun 2014. PPN Palabuhanratu. Sukabumi.

PPN Palabuhanratu Kementrian Kelautan dan Perikanan. 2016. Buku Laporan Tahunan Statistik Perikanan Tangkap Tahun 2015. PPN Palabuhanratu. Sukabumi.

PPN Palabuhanratu Kementrian Kelautan dan Perikanan. 2017. Buku Laporan Tahunan Statistik Perikanan Tangkap Tahun 2016. PPN Palabuhanratu. Sukabumi.

PPN Palabuhanratu Kementrian Kelautan dan Perikanan. 2018. Buku Laporan Tahunan Statistik Perikanan Tangkap Tahun 2017. PPN Palabuhanratu. Sukabumi.

PPN Palabuhanratu Kementrian Kelautan dan Perikanan. 2019. Buku Laporan Tahunan Statistik Perikanan Tangkap Tahun 2018. PPN Palabuhanratu. Sukabumi.

Samosir A. 2014. Sektor Perikanan: PNBP YANG TERABAIKAN. https: //www. kemenkeu.go.id/sites/default/files / sektor_perIkanan_060314.pdf. Oktober 2019].

Setyorini, Suherman A, Triarso I. 2009. Analisis Perbandingan Produktivitas Usaha Penangkapan Ikan Rawai Dasar (Bottom Set Long Line) dan Cantrang (Boat Seine) di Juwana Kabupaten Pati. Jurnal Saintek Perikanan. 5(1): 7-14.

Sinungan M. 2008. Produktivitas Apa dan Bagaimana. Bumi Aksara. Jakarta. 